\title{
DA (IM) POSSIBILIDADE DE DECLARAÇÃO EX OFFÍCIO DA PRESCRIÇÃO TRIBUTÁRIA PELA AUTORIDADE ADMINISTRATIVA
}

\author{
Simone Cruz Nobre ${ }^{1}$
}

\section{RESUMO}

A prescrição pode ser declarada de ofício pelo magistrado. Contudo, a prescrição pode ocorrer na esfera administrativae, realizar a inscrição em dívida ativa e ajuizaração que sabe indevida, acaba por ferir princípios da Administração Pública. Muito se defende que esse procedimento seria um poder-dever e sua declaração pode ser procedida ex offício. Há Estados em que a competência para realizar estes atos não estão condensadas na mesma autoridade administrativa. Assim, faz-se necessário avaliar se a declaração não conflita com a competência legal exclusiva do agente público. Estaria este ato amparado no poder de autotutela?

Palavras-chave: Prescrição Tributária Administrativa; Crédito Tributário; Segurança Jurídica; Autotutela; Competência legal.

\section{THE (IM) POSSIBILITY OF DECLARATION EXECUTIVE OF THE TAX PRESCRIPTION BY THE ADMINISTRATIVE AUTHORITY}

\begin{abstract}
The prescription can be declared ex officio by the magistrate. However, the prescription can occur in the administrative sphere and, to carry out the registration in active debt and to file an action that knows unduly, ends up violating principles of the Public Administration. It is widely argued that this procedure would be a power-of-duty and its declaration may be proceeded ex officio. There are States in which the competence to carry out these acts is not condensed in the same administrative authority. Thus, it is necessary to assess whether the declaration does not conflict with the exclusive legal competence of the public agent. Was this act protected by the power of self-order?
\end{abstract}

Keywords: Administrative Tax Prescription; Tax Credit; Legal Security; Self-order; Legal Competence.

\section{INTRODUÇÃO}

A prescrição é a perda da pretensão de exigir a satisfação de um direito que possui o seu titular, em função da sua inérciano decurso do prazo estabelecido em lei.

\footnotetext{
${ }^{1}$ Mestre em Direito, Políticas Públicas e Direitos Humanos pelo Centro Universitário do Estado do ParáCESUPA. Pós-graduada em Direito Tributário pela Fundação Getúlio Vargas - FGV. Auditora Fiscal de Receitas Estaduais do Estado do Pará.
} 
No entanto, a prescrição no direito tributário extingue não apenas a pretensão do direito de cobrança, mas o próprio direito material que é o pressuposto legal para ajuizamento da ação de execução. Com a prescrição o crédito tributário perde a sua força coercitiva.

Desta forma, não parece razoável realizar a inscrição e/ou o ajuizamento de uma demanda judicial de um crédito que não mais possui.

O Parecer PGFN/CDA no 877/2003 demonstra estar pacificado, no âmbito da Procuradoria Geral da Fazenda Nacional, a tese pelo reconhecimento administrativo ex officio da prescrição executória como um poder-dever de autotutela. Logo, independe da provocação do sujeito passivo.

No entanto, nos tributos de competência do Estado e naqueles em que há uma cisão nestes atos, ou seja, quando o ato de inscrição em dívida ativa é de competência da Secretaria de Estado da Fazenda e a execução fiscal é promovida pela Procuradoria do Estado, caberia a quem a declaração ex offício da prescrição administrativa, na ausência de lei autorizativa?

O cerne da questão, portanto, é verificar se o dever de agir, necessário para a prática do ato, pode ser fundamentado no seu poder de autotutela ou se haveria incompatibilidades com as suas competências funcionais.

Não podemos nos furtar desta discussão, posto que em algumas unidades da federação, como no Estado do Pará, este conflito ainda não resta pacificado, gerando insegurança jurídica e lentidão administrativa, em pleno descompasso com os princípios da eficiência, da segurança jurídica, da razoabilidade, da economicidade e da moralidade que devem nortear o agirda Administração Pública.

O presente estudo se propõe a verificar o instituto da prescrição e a sua íntima relação com o princípio da segurança jurídica, avaliando o momento em que se inicia o prazo prescricional, bem como, o iter constitutivo do crédito tributário.

Adentraremos na verificação das competências das autoridades administrativas envolvidas e o poder de autotutela frente ao silêncio da lei.

O fato é que, muito embora a declaração da prescrição seja um direito do sujeito passivo, na ausência de autorização expressa, há de se avaliar a quem caberia o 
seu reconhecimento, tendo em vista que não é competente quem quer, mas quem disponha de atribuição compatível para a sua pronúncia.

\section{A PRESCRIÇÃO E O DIREITO FUNDAMENTAL À SEGURANÇA JURÍDICA}

O tempo rege a vida em uma sociedade seja inaugurando, modificando ou estabilizando as relações sociais. É, portanto, elemento jurídico natural de fundamental importância às relações jurídicas, posto ser apto para demarcar a aquisição ou extinção de direitos.

Sendo elemento essencial, é imprescindível nas relações obrigacionais que a lei estabeleça o marco temporal a partir do qual haja uma perpetuidade nas relações jurídicas, garantindo, assim, a pacificação social.

Desta forma, não seria razoável crer que a lei faculte ao sujeito, titular do direito à determinada pretensão, o poder de cobrança sem qualquer delimitação temporal. Se o titular deseja ver reconhecido o seu direito e, se este é, de fato, imprescindível, deve reivindicá-lo em um prazo razoável. Isto porque, se demonstra desinteresse em vê-lo adimplido, não há razão para o resguardar. Assim, a inércia no exercício do direito pelo credor permite que o decurso do tempo sedimente as relações interpessoais da forma como se encontram.

É salutar, portanto, que o reconhecimento do direito ao cumprimento de determinada obrigação seja exercido até certo momento, sob pena de operar a sua extinção, posto que permitir ao seu titular o poder de cobrança a qualquer tempo, não permite a estabilidade jurídica, a certeza e a paz no trato dos conflitos.

Seguindo esta linha interpretativa, Gagliano e Pamplona Filho (2007, p.455) pontuam:

O exercício dos direitos, seja no campo das relações materiais, seja por ações judiciais, deve ser uma consequência e garantia de uma consciência de cidadania, e "não uma ameaça" contra os sujeitos obrigados, que não devem estar submetidos indefinidamente a uma "espada de Dômocles" sobre as suas cabeças. 
Com efeito, se o tempo opera modificação constante no direito, espera-se que o seu detentor não permita que o tempo retire o seu. Como diz o brocardo jurídico: Dormientibus non succurit jus, ou seja: o direito não socorre aos que dormem.

Bevilláqua (1978 apud MONTEIRO, 1985, v. 1, p.162) discorria: “a prescrição é a perda da ação atribuída a um direito, e de toda sua capacidade defensiva, em consequência do não uso dela, durante determinado espaço de tempo".

Como a cada direito deve existir uma ação à sua real garantia, a prescrição, inicialmente, foi conceituada como a perda do direito de ação.

Posteriormente, a noção de prescrição recebe uma análise mais acura e cristalizou-se a ideia de autonomia da relação jurídica processual, que envolvia as partes e o juiz, da relação material litigiosa (TONIOLO, 2008, p.20). Logo, o direito de acesso ao judiciário, por meio do ajuizamento de uma ação, não se confunde com o próprio direito material protegido.

Somente com o advento do Código Civil de 2002, o conceito de prescrição adere ao novo olhar, levando Theodoro Júnior (2005, p. 57) a pontuar que: "A prescrição faz extinguir o direito de uma pessoa exigir de outra uma prestação (ação ou omissão), ou seja, provoca a extinção da pretensão, quando não exercida no prazo definido em lei."

Corroborando com essa nova conformação, Toniolo (id., p.27) assevera: "Vencido o título, torna-se exigível o cumprimento do dever junto ao sujeito passivo da relação jurídica. Estaria agregada ao direito subjetivo a "pretensão", isto é, a faculdade de poder reclamar a satisfação de um Direito Material.”

Observa-se que a prescrição é um instituto que surge, inicialmente, no âmbito das relações privadas e, posteriormente, alcança forte influência sob o agir do ente público, tendo, inclusive, assento no texto constitucional, senão vejamos:

Art. $7^{\circ}$ São direitos dos trabalhadores urbanos e rurais, além de outros que visem à melhoria de sua condição social:

$[\ldots]$

XXIX - ação, quanto aos créditos resultantes das relações de trabalho, com prazo prescricional de cinco anos para os trabalhadores urbanos e rurais, até o limite de dois anos após a extinção do contrato de trabalho; 
A prescrição, também, é reconhecida em vários ramos do Direito. O art. $189^{2}$ do Código Civil aduz que, uma vez violado o direito, nasce para o titular a pretensão de exigir o seu reconhecimento, pelo prazo que a lei fixar, e que, caso não exercido, será extinto pela prescrição. Este prazo, conforme dispõe o art. 205 do CC, prescreverá em 10 (dez) anos se a lei não prever prazo menor.

Ademais, nos termos do $\S 1^{\circ}$ do art. 332 do novo Código de Processo Civil, o juiz poderá julgar liminarmente improcedente o pedido se verificar, desde logo, a ocorrência da decadência ou prescrição. Caso não observado estes institutos na fase preliminar, o magistrado necessitaria oportunizar às partes o direito de manifestação, de forma a garantir o contraditório e ampla defesa.

Por sua vez, o inciso IV do art. 107 do Código Penal aduz que a punibilidade se extingue pela prescrição, sendo que o art. 109 delimita o seu prazo prescricional, a depender da pena prevista para a conduta criminosa praticada.

Na seara tributária, a alínea "c" do inciso III do art. 146 da Constituição Federal estabelece a necessidade de Lei Complementar para a regulamentação da prescrição.

O Código Tributário Nacional, norma com status de lei complementar, regulamenta a prescrição, em harmonia com os demais ramos do direito, ao estabelecer, no caput do art. 174, a perda do direito de ação, caso não exercida dentro do prazo prescricional de cinco anos de sua constituição definitiva. Define, ainda, no art. 156, V, que a prescrição extingue com opróprio direito material ao crédito tributário.

Assim, cumpridos os requisitos para que declare a prescrição, esta passa a ser de reconhecimento obrigatório em favor daquele que com esta possa se beneficiar dos seus efeitos.

Ademais, com as transformações sociais e a necessidade de um Estado mais atuante que garanta e reconheça direitos, mas, ao mesmo tempo, promova a harmonia e a estabilidade social, o instituto da prescrição, passa ser traduzida como sinônimo de segurança jurídica. Isto porque, segundo Ávila (2012, p.115), na sua acepção como norma-princípio, “a segurança jurídica diz respeito a um estado de coisas que deve ser

\footnotetext{
${ }^{2}$ Art. 189. Violado o direito, nasce para o titular a pretensão, a qual se extingue, pela prescrição, nos prazos a que aludem os arts. 205 e 206.
} 
buscado mediante a adoção de condutas que produzam efeitos que contribuem para a sua promoção".

Desta forma, se o Estado deve cumprir com sua função planificadora e indutora da sociedade, a segurança jurídica tributária deve ser entendida como um estado de cognicidade, de confiabilidade e calculabilidade, ou seja, o cidadão deve compreender as alternativas normativas, bem como, ter confiança que dentro do prazo legal estabelecido, as consequências jurídicas serão efetivamente aplicadas. Logo, pode ser traduzida como uma garantia individual assegurada ao cidadão de uma expectativa legítima à estabilidade a ser exercitada, inclusive, face à atuação estatal (ÁVILA, 2012, p.272).

Assim a ordem jurídica deve corresponder a um quadro normativo estabelecido para que a partir dele as pessoas possam se orientar, sabendo o que podem e o que não podem fazer, tendo em vista as consequências imputáveis aos atos praticados (MELLO, 2009, p.124).

Se a Constituição Federal confere no art. $5^{\circ}$ a toda e qualquer pessoa vários direitos irrenunciáveis concernentes à vida, à liberdade, à igualdade, à segurança e à propriedade, tais direitos passam a ser oponíveis a qualquer pessoa, e, também, ao próprio Estado.

Desta forma, como sinônimo de segurança jurídica, a prescrição passa a ser entendida como um direito fundamental, e, portanto, indisponível. Sendo um direito fundamental, possui o seu reconhecimento obrigatório, uma vez tratar-se de norma de ordem pública, salvo as situações excepcionais ${ }^{3}$.

\section{A PRESCRIÇÃO TRIBUTÁRIA ADMINISTRATIVA}

Sabe-se que a relação jurídica tributária surge a partir do lançamento, ato administrativo tendente a identificar o sujeito passivo, constatar a efetivação da hipótese de incidência tributária e calcular o quantum devido. Isto é, "o lançamento consiste num ato de aplicação normativa composto por um conjunto de enunciados prescritivos a

\footnotetext{
${ }^{3}$ A prescrição não ocorre contra o incapaz; ações que protegem o direito de personalidade
} 
partir dos quais poderá ser constituída a regra tributária individual e concreta." (CERQUEIRA, 2000, p.198).

Antes do lançamento, o direito existe, mas não pode ser exigido, posto que o lançamento acrescenta o efeito jurídico de exigibilidade àquele direito preexistente (BECKER, 2010, p.383). O lançamento é, portanto, ato administrativo apto a evitar a decadência tributária. Isto porque, se o lançamento foi realizado após o prazo decadencial, o crédito o qual buscou-se constituir nem chegou a ser efetivar, uma vez estar falecido o direito subjetivo material do fisco de fazê-lo.

A prescrição, a seu turno, diferentemente da decadência, opera efeitos sobre a juridicidade do título executivo, situação que retira do fisco a pretensão ao crédito tributário (SANTI, 2010, p.164).

Com efeito, a pretensão é o direito de se exigir em juízo crédito tributário definitivamente constituído, dentro do prazo legal, sob pena de, não o observando, sofrer uma sanção que será a prescrição de seu crédito.

Assim, nos termos do art. 174 do Código Tributário Nacional, para que o crédito tributário seja exigido, faz-se necessário a sua constituição definitiva.

Seguindo a inteligência da súmula vinculante n. ${ }^{\circ} 24$ do Supremo Tribunal Federal, a constituição definitiva do crédito somente ocorre com o encerramento da discussão na esfera administrativa.

Sabe-se que, de uma forma geral, os tributos têm sua constituição definitiva em duas situações: i) com a declaração do contribuinte de ter incorrido nas hipóteses de incidência tributária, mas deixando este de recolher o imposto devido; ii) com o ato final do procedimento de lançamento, sem questionamentos por parte do contribuinte, ou, em sendo este impugnado, somente quando confirmado pela decisão administrativa irreformável.

Assim, em respeito à segurança jurídica o crédito reveste-se de definitividade na esfera administrativa quando não sujeito às hipóteses do art. 145 do CTN.

Art. 145. O lançamento regularmente notificado ao sujeito passivo só pode ser alterado em virtude de:

I - impugnação do sujeito passivo;

II - recurso de ofício; 
III - iniciativa de ofício da autoridade administrativa, nos casos previstos no artigo 149

Desta forma, o crédito tributário devidamente constituído, mas sem que o ente público busque garantir, em um determinado lapso temporal, o seu direito poderá ser extinto pela prescrição. Logo, podemos verificar que são pressupostos para que se declare a prescrição tributária: i) a inércia do titular do direito; ii) o decurso do prazo estabelecido em lei.

É mister ressaltar que a contagem do prazo prescricional, contudo, não se realiza sem controvérsias, tendo em vista que as situações de suspensão e interrupção do crédito tributário.

Face a essas controvérsias, há o enunciado de Súmula n. ${ }^{\circ} 409$ do Superior Tribunal de Justiça com o seguinte verbete: "Em execução fiscal, a prescrição ocorrida antes da propositura da ação pode ser decretada de oficio".

Ora, mas se o Código Tributário Nacional aduz hipóteses de interrupção da prescrição para as situações levadas ao Juízo e a Lei n. ${ }^{\circ}$ 6.830/80 situações de suspensão do crédito tributário, bem como regula a prescrição intercorrente na via judicial, seria possível o ente público declarar prescrito um crédito tributário antes do ajuizamento da ação de cobrança, deixando de inscrevê-lo em dívida ativa ou, se já inscrito, não ajuizar a demanda?

Se a indagação está relacionada a créditos tributários de competênciada União, não há qualquer dúvida quanto a sua pertinência, posto que, nos termos do art. $1^{\circ}-\mathrm{C}$ da 9.469 , de 10 de julho de 1997, alterado pela Lei n. ${ }^{\circ} 11.941$, de 27 de maio de 2009, a Procuradoria da Fazenda Nacional é autorizada a não inscrever o crédito tributário. Senão vejamos:

Art. $1^{\circ}$-C. Verificada a prescrição do crédito, o representante judicial da União, das autarquias e fundações públicas federais não efetivará a inscrição em dívida ativa dos créditos, não procederá ao ajuizamento, não recorrerá e desistirá dos recursos já interpostos.

Ademais, o art. 53 da Lei n. ${ }^{\circ} 11.941$, de 27 de maio de 2009, autoriza que esta seja reconhecida de ofício pela autoridade administrativa. ${ }^{4}$ Inclusive, poderá ser

\footnotetext{
${ }^{4}$ Art. 53 A prescrição dos créditos tributários pode ser reconhecida de ofício pela autoridade administrativa.
} 
declarada mesmo que não invocada pelo sujeito passivo, evitando demandas judiciais desnecessárias, em perfeita consonância com o princípio da eficiência, esculpido no caput do art. 37 da Constituição Federal.

Essa nova interpretação altera o a interpretação dada à portaria MF n. ${ }^{\circ} 259$, de 28 de maio de 1980, que assim determinava:

O Ministro de Estado da Fazenda, no uso de suas atribuições,

RESOLVE:

I - Os processos contenciosos administrativos, referentes a créditos da União, tributários ou não, em curso perante os órgãos singulares ou coletivos, vinculados ao Ministério da Fazenda, serão por estes apreciados sem levar em consideração a possível ocorrência de prescrição, a não ser que seja expressamente invocada pelo sujeito passivo.

II - Na hipótese de o sujeito passivo invocar expressamente a ocorrência da prescrição, a autoridade, que tomar conhecimento da argüição, sobre ela se pronunciará e, se a julgar procedente, deverá adotar as providências de sua alçada, no sentido de apuração da responsabilidade funcional pela extinção do crédito, se for $o$ caso.(grifo nosso)

Nesta esteira de raciocínio, a declaração de ofício da prescrição pela administração pública, no âmbito da Receita Federal do Brasil, independentemente de arguição pelo sujeito passivo, foi objeto de Solução de Consulta Interna n. ${ }^{\circ} 25$ - Cosit, em 5 de setembro de $2013^{5}$, onde se questionava se acepção da expressão "pode ser reconhecida de ofício" seria uma mera faculdade ou um poder-dever. Em resposta, a Cosit assim exarou o seguinte entendimento:

Fica patente que a base principiológica do art. 53 da Lei $n^{\circ} 11.941$, de 2009, é o Princípio da Eficiência, de forma a dar mais celeridade e economizar recursos na atuação da Administração Pública, evitando a propositura de ações de execução fiscal intempestivas.

[...]

Assim, entende-se que o reconhecimento de ofício da prescrição de um crédito tributário, quando esta for conhecida pela autoridade administrativa, é um poder-dever, e não uma mera faculdade dada à autoridade administrativa. A eventual escolha pelo não reconhecimento da prescrição de um crédito tributário de

\footnotetext{
${ }^{5}$ SOLUÇÃOdE CONSULTA INTERNAN. ${ }^{\circ}$ 25- minutada por Julio Cesar de Sousa Marinho, AuditorFiscal da RFB da Disit da $8^{\text {a }}$ Região Fiscal, com revisão de Eduardo Newman de Mattera Gomes, chef da Disit da $8^{a}$ Região Fiscal. Analisado por Eduardo Gabriel Góes Vieira Ferreira Fogaça, chefe da Dinog, com revisão de Mirza Mendes reis, Coordenadora da Copen.
} 
conhecimento da autoridade administrativa equivaleria a concluir pela inoportunidade ou inconveniência da atuação eficiente da Administração Pública, o que representaria tornar inócuo um princípio constitucionalmente estabelecido.

E concluiu: "Por todo o exposto, o vocábulo "poder" inserto no art. 53 da Lei $n^{\text {o }} 11.941$, de 2009, deve ser interpretado como "poder-dever". O reconhecimento de ofício de prescrição é poder-dever da Autoridade Fiscal administrativa, cuja atuação é vinculada." $" 6$

No Estado do Rio de Janeiro, o art. 194 do Decreto-lei 05/75, alterado pela Lei n. ${ }^{\circ}$ 2.207/93 autoriza a não inscrição em dívida ativa, bem como a não execução ou, até mesmo, a sua desistência, se o crédito tributário estiver prescrito. Senão vejamos:

Art. 194. A cobrança judicial e extrajudicial da dívida ativa do estado do Rio de Janeiro a que se refere o $§ 6 .^{\circ}$ do artigo 176 da Constituição Estadual é de competência privativa dos Procuradores do Estado, sem prejuízo das atribuições conferidas pelo artigo 132 da Constituição Federal, pela Lei Complementar n. ${ }^{\circ}$ 15, de 15 de novembro de 1980, e demais legislações aplicáveis.

$\S 1 .^{\circ}$ Esgotado o procedimento administrativo relativo a crédito do Erário, o respectivo processo será imediatamente remetido à Procuradoria Geral do Estado para efeito de inscrição em dívida ativa e cobrança amigável ou contenciosa.

$\S 2 .^{\circ}$ A Procuradoria Geral do Estado não inscreverá crédito prescrito, nem promoverá ou prosseguirá a cobrança judicial de dívida ativa prescrita. (grifo nosso)

À semelhança do Estado do Rio de Janeiro, na grande parte dos Estados brasileiros $^{7}$, os atos de inscrição em dívida ativa, bem como a execução dos títulos executivos extrajudiciais é procedimento de competência da Procuradoria do Estado.

No entanto, nos tributos de competência do Estado e naqueles em que há uma cisão nestes atos, ou seja, quando o ato de inscrição em dívida ativa é de competência da Secretaria de Estado da Fazenda e a execução fiscal é promovida pela Procuradoria do Estado, a declaração ex offício da prescrição administrativa, caberia a quem?

${ }^{6}$ Ibid.

${ }^{7}$ O mesmo ocorre nos Estados de São Paulo, Bahia, Minas Gerais, Paraná, Rio Grande do Sul, Amazonas, Acre, Pernambuco, entre outros. 


\section{A DECLARAÇÃO DA PRESCRIÇÃO ANTES DO AJUIZAMENTO DA AÇÃo DE EXECUÇÃO}

A prescrição administrativa pode ser verificada em dois momentos: i) antes da inscrição do crédito em dívida ativa; ii) após a emissão da certidão, mas antes do ajuizamento da ação.

Nos Estados em que há autorização expressa em lei para a inscrição ou o não ajuizamento da ação de execução, identificando a autoridade administrativa competente para declarar, a prescrição se faz sem dificuldade face à previsão legal e os princípios que orientam os atos administrativos. No entanto, quando há um silêncio normativo, mas sabendo que a declaração da prescrição é direito do contribuinte, quem teria a competência para declarar ex offício a prescrição?

\subsection{A Declaração da prescrição antes da emissão em dívida ativa}

Antes da emissão da certidão negativa, o crédito tributário está sujeito a um iter constitutivo para adquirir exigibilidade.

Sabe-se que a autoridade fazendária é competente para proceder ao lançamento tributário, cuja atividade, nos termos do parágrafo único do art. 142 do Código Tributário Nacional é vinculada.Ou seja, caso devido o tributo, o seu não lançamento está sujeito à pena de responsabilidade funcional.

Em verdade, trata-se de norma que tem como pressuposto a competência da autoridade fazendária para realizar um procedimento de quantificação e de publicidade, tendo em vista o fato jurídico tributável. Assim, existe uma prévia e objetiva tipificação legal que é motivo do ato e que confere ao agente público competente o dever de praticá-lo.

No momento do lançamento tributário o agente público irá aferir os elementos necessários para a constituição do crédito. Logo, irá verificar se houve, no caso concreto, a ocorrência da hipótese de incidência tributária, o sujeito passivo sujeito à imposição, o local da prática do fato e o quantum devido.

Dentro dessa competência legal atribuída à autoridade fazendária, está a de verificar se ainda vige o direito do fisco de praticar o ato de lançamento. Isto porque a decadência suprime o direito subjetivo deste formalizar o crédito tributário. 
A decadência, segundo Pereira (1993, p.479): "é o perecimento do direito, em razão do seu não exercício em um prazo determinado". A decadência atinge o direito material, ou seja, o fundamento legal para realizar o lançamento. Assim, a lei apenas confere competência para a prática do ato de lançamento enquanto não decaído, pelo prazo estabelecido em lei, o seu direito.

O lançamento tributário assume, portanto, uma dupla função: i) delimitar no plano fático o quanto devido na relação jurídica tributária; ii) afastar a decadência tributária. O lançamento é, portanto, o divisor de águas entre a decadência e a prescrição.

Nesta senda, quando a lei confere competência à autoridade fazendária à praticado ato de lançamento, está determinando ao servidor analisar todos os pressupostos do ato, inclusive, verificar se ainda persiste o direito subjetivo administrativo do fisco em formalizá-lo.

O fato é que, neste momento, a competência restringe-se tão somente em relação à decadência, posto que a prescrição envolveria a análise de algo que apenas teria aptidão para surgir em fase posterior ao lançamento.

Após o lançamento, em regra, a autoridade fiscal encerra sua competência legal quanto à pratica do ato em relação àquele sujeito passivo, limitando-se tão somente a revisá-lo,caso verifique alguma hipótese de inexatidão. É a revisão de ofício a que está sujeito qualquer crédito tributário.

Assim, faz-se mister reconhecer que o agir público, no caso da constituição do crédito tributário com vistas a arrecadação das receitas públicas, não é uma faculdade, mas uma obrigação irrenunciável, tendo em vista a indisponibilidade do interesse público. Trata-se de um poder que não comporta margem de discricionariedade.

Com efeito, como comentado anteriormente, a prescrição tributária, em princípio, somente produz efeitos após a constituição definitiva, tendo em vista que durante a fase de impugnação ou recurso de ofício o crédito está com sua exigibilidade suspensa.

Seria, então,a declaração da prescrição administrativa ex offício um ato de competência da autoridade fiscal responsável pela sua inscrição em dívida ativa? 
Sabe-se que o ato de inscrição em dívida ativa, em alguns Estados brasileiros $^{8}$, compete à própria Secretaria da Fazenda. No entanto, se esta autoridade fiscal verificar que o crédito tributário prescreveu pela inércia da própria administração em proceder à inscrição, o agente público tem competência para deixar de inscrever e declarar a prescrição administrativa ex offício?

No caso do Estado do Pará, a Lei Complementar n. ${ }^{\circ}$ 58, de 1 de agosto de 2006, Código de direitos, garantias e obrigações dos Contribuinte, veda a inscrição em dívida ativa de crédito ${ }^{9}$. Há, portanto, um permissivo legal que determina o non facere em relação à inscrição. No entanto, mostra-se silente em relação à autoridade administrativa para a declaração.

$\mathrm{O}$ fato é que a expressão ex offício significa um agir em face às competências que lhe são outorgadas em lei.

Assim, tendo em vista o permissivo acima, mas na ausência de definição expressa, pode-se afirmar que a declaração da prescrição administrativa seria uma decorrência do poder de autotutela da Administração Pública?

Com efeito, a autotutela é o poder que orienta a administração para a correção de seus próprios atos, revogando os que não se mostrem mais convenientes ou oportunos, bem como, anulando os atos ilegais. É o dever de vigilância dos atos confiados sob a sua guarda.

Carvalho Filho (2009, p.154), ao discorrer sobre autotutela pontua que "Em outras palavras, significa que, se for necessário rever determinado ato ou conduta, a Administração poderá fazê-lo ex offício, usando sua auto-executoriedade, sem que dependa necessariamente de que alguém o solicite".

Este entendimento é defendido em função ao enunciado de Súmula n. 473 do STF, que preceitua:

A Administração Pública pode anular seus atos, quando eivados de vícios que os tornem ilegais, porque deles não se originam direitos, ou revogâ-los, por motivo de conveniência e oportunidade, respeitados os direitos adquiridos e ressalvada, em todos os casos, a apreciação judicial. (grifo nosso)

\footnotetext{
${ }^{8}$ Nos Estado do Pará, do Ceará, Espírito Santo, por exemplo, a responsabilidade pela inscrição em dívida ativa é de competência da Secretaria de Estado da fazenda.

${ }^{9}$ Art. 21 É vedado à autoridade administrativa, tributária e fiscal, sob pena de responsabilidade: [...] XI inscrever o crédito tributário em dívida ativa ou ajuizar ação executiva fiscal quando souber indevida;
} 
Sabe-se que os poderes da administrativos são conferidos aos agentes públicos, de forma a lhe impor o exercício sempre que voltados aos interesses da coletividade (CARVALHO FILHO, 2009, p.42). No entanto, esse dever de agir pressupõe um ato administrativo que pode ser tanto comissivo (facere) como omissivo (non facere).

O não pronunciamento da prescrição pela autoridade fiscal representa um ato omissivo. No entanto, o poder de autotutela pressupõe um vício no ato e, se há uma lei autorizativa apenas quanto a não inscrição, mas silente em relação à autoridade, há de ser observado se esta omissão é do tipo genérica ou específica, posto que nem toda omissão é ilegal, ao ponto de justificar o poder de autotutela.

Segundo Carvalho filho (Id., p.42), a omissão genérica permite "ao administrador avaliar a oportunidade e conveniência para adotar as providências positivas". Por sua vez, as omissões específicas são aquelas em que há expressa imposição legal para agir, mas o administrador permanece inerte.

Neste sentido, Carvalho filho (Id., p.43) pontua:

ilegais são as omissões específicas, ou seja, aquelas que estiverem ocorrendo mesmo diante de expressa previsão legal no sentido de facere administrativo em prazo determinado, ou ainda quando, mesmo sem prazo fixado, a Administração permanece omissa em período superior ao aceitável dentro de padrões normais de tolerância ou razoabilidade.

Desta forma, a omissão somente passa a ser ilegal quando exista uma previsão legal para agir. Nesta situação, faz-se necessário um poder-dever de agir expresso em dispositivo legal.

O fato é que o exercício do direito de autotutela exige que se anule o ato quando eivados de ilegalidade. Neste sentido, ressalvadas as imprecisões em sua inscrição, passíveis de correção, a ilegalidade no crédito tributário capaz de justificar sua anulação, somente poderia estar relacionada a situações de decadência tributária, posto que seria um ato comissivo ilegal da autoridade fiscal em ter lançado uma obrigação tributária já extinta, ou, como no caso do Estado do Pará, que a lei determine o non facere e a autoridade realize a inscrição em dívida ativa de algo que não seja mais exigível. 
O poder de autotutela nada poderia dizer em relação à declaração da prescrição, tendo em vista que, após a constituição válida do crédito tributário, a inércia na pratica do ato de inscrição é efeito externo ao crédito devidamente constituído e deve estar sujeito ao poder disciplinar.

O fato é que se a Administração Pública não se pronuncia quando deveria o fazer, seja por iniciativa própria de controle de seus atos ou a requerimento do sujeito passivo, ocorre um silêncio administrativo.

Em alguns casos a lei atribui efeitos ao silêncio, considerando deferido ou não o pleito do contribuinte caso a Administração não se pronuncie.

No entanto, o silêncio administrativo não é um ato jurídico. Mello (2009, p.408) discorre:

Na verdade, o silencio não é ato jurídico. Por isso, evidentemente, não pode ser ato administrativo. Este é uma declaração jurídica. Quem se absteve de declarar, pois, silenciou, não declarou nada e por isto não praticou ato algum. Tal omissão é um "fato jurídico" e, in casu, um "fato jurídico administrativo". Nada importa que a lei haja atribuído determinado efeito ao silêncio: o de conceder ou negar. Este efeito resultará do fato da omissão, como imputação legal, e não de algum presumido ato, razão por que é de rejeitar a posição dos que consideram ter aí existido um "ato tácito".

Como se pode inferir, o poder de autotutela pressupõe um ato, mas se este ato omissivo não está previsto em lei, não se pode dizer ilegal. Muito embora a omissão não deixe de ser uma forma de violação do direito e do próprio dever funcional do exercício com zelo e dedicação às atribuições do cargo" (MELLO, 2009, p.409), a verdade é que, faz-se imperiosa a lei para autorizar a autoridade fiscal a declarar prescrito o crédito tributário, posto que a declaração da prescrição envolveria renunciar a prerrogativa que tem o poder público de constituir o crédito tributário, o que, sem dúvida, também representa interesses da sociedade, a maior beneficiária dos produtos e serviços que as receitas públicas financiam. Se a lei é silente, a declaração da prescrição ex ofício, requer respeitar as competências atribuídas às autoridades administrativas.

Como de brilhantemente leciona Meireles (1994, p.156):

No desempenho dos encargos administrativos o agente do Poder Público não tem a liberdade de procurar outro objetivo ou de dar fim diverso do prescrito em lei para a atividade. Não pode, assim, deixar de cumprir os deveres que a lei impõe, nem renunciar a qualquer parcela de poderes e prerrogativas que lhe são conferidos. Isso porque 
os deveres, poderes e prerrogativas não lhe são outorgados em consideração pessoal, mas sim para serem utilizados em benefício da comunidade administrada.

Descumpri-los ou renunci-á-los equivalerá a descumprir a incubência que aceitou ao impossar-se no cargo ou função pública. Por outro lado, deixar de exercer e defender os poderes necessários à consecução dos fins sociais que constituem a única razão de ser da autoridade pública de que é investido, importará renunciar os meios indispensáveis para atingir os objetivos da administração.

Em última análise, os fins da administração consubstanciam-se na defesa do interesse público, assim entendidas aquelas aspirações ou vantagens licitamente almejadas por toda a comunidade administrada, ou por parte expressiva de seus membros.

Nesta senda, embora a autoridade fiscal disponha de conhecimentos tributários e saiba-se que a prescrição, à semelhança da decadência, extingue o direito material subjetivo ${ }^{10}$, o fato é que a prescrição, como perda da pretensão do direito de ação, diz respeito, não somente quanto ao direito material, mas, também, à viabilidade da cobrança judicial, cuja nuance foge à sua esfera de competência da autoridade fiscalpara manifestação.

O fato é que, muito embora a lei não determine a quem cabe pronunciar a prescrição, não retira a necessidade de o intérprete da norma o fazer, utilizando-se para tanto uma interpretação sistêmica com os demais ramos do direito. Como bem resume o Ministro Luís Roberto Barrosos (2002, p.501): “O fato de não haver uma norma dispondo especificamente acerca do prazo prescricional, em determinada hipótese, não confere a qualquer pretensão a nota de imprescritibilidade".

Logo, a fim de conferir eficácia ao direito individual do sujeito passivo de ver extinto o crédito tributário constituído, haveria necessidade, respeitadas as competências legais para a prática do ato, ser a declaração da prescrição administrativa realizada em ato sujeito à manifestação tanto da autoridade fiscal quanto do Procurador do Estado, sem prejuízo da apuração da responsabilidade funcional.

Isso porque, ainda que se entenda que a perda do direito material possua, como decorrência lógica, a aptidão de inviabilizar atos processuais, faz-se necessário, no silêncio normativo, respeitar as competências que cada autoridade dispõe, posto que

\footnotetext{
${ }^{10}$ Art. 156, inciso V do Código Tributário Nacional.
} 
a competência é fundamental para legitimar a atuação pública e garantir plena observância ao princípio da legalidade.

\subsection{A Declaração da Prescrição após a inscrição em Dívida Ativa e antes do Ajuizamento da Ação de Execução}

Como já destacado acima, o crédito tributário também pode prescrever após a inscrição em dívida ativa, mas antes do ajuizamento da ação de execução. Nesta situação, uma vez verificado que o crédito tributário prescreveu face à possível inércia do Procurador do Estado em ajuizar a ação executiva, levando à inviabilidade ou impossibilidade no êxito da defesa do crédito anteriormente constituído, deveria, ainda assim,este ajuizar a ação de execução fiscal ou é seu poder-dever declará-la ex offício?

É importante destacar que cabe à Procuradoria do Estado patrocinar os interesses do Estado, em juízo ou fora dele. Logo, é sua competência zelar pela constitucionalidade dos atos da Administração Pública e pela observância dos princípios constitucionais a ela aplicáveis ${ }^{11}$.

O reconhecimento de ofício da prescrição do crédito tributário ainda em âmbito administrativo é medida que se impõe como vetor à aplicação do princípio da eficiência, da segurança jurídica, da moralidade e da própria legalidade do ato administrativo.

Ajuizar uma ação que se sabe de antemão ilegal, afronta o princípio da eficiência, face aos custos desnecessários gerados diante da certeza de sua improcedência. Afeta o princípio da moralidade, posto que macula um dos atributos que reveste o ato administrativo: a presunção de legitimidade e veracidade, em frontal descompasso com o princípio da boa-fé.

Além disso, afronta o princípio da legalidade, uma vez que realiza cobrança sem estar acobertado pelo crédito tributário que se alega possuir. Vale ressaltar que a prescrição do crédito tributário retira não apenas a pretensão da ação, mas o próprio direito material do fisco.

\footnotetext{
${ }^{11}$ Inciso VII do art. $2^{\circ}$ da Lei Complementar do Estado doPará n. ${ }^{\circ}$ 41/2002.
} 
$\mathrm{O}$ ajuizamento de uma ação fiscal que saiba ineficiente à recuperação do crédito tem o condão de afrontar a razoabilidade. $\mathrm{O}$ elevado custo com o ajuizamento desse tipo de demanda, não apenas pelos vários atores envolvidos, como também pela possibilidade de ser condenada aos honorários advocatícios já são razões suficientes para acenar à sua inviabilidade.

Isso porque,há de se destacar que segundo o enunciado de Súmula n. ${ }^{\circ} 153$ do STJ: "A desistência da execução fiscal, após o oferecimento dos embargos, não exime o exeqüente dos encargos da sucumbência". Ademais, o parágrafo único do art. 39 da Lei de execução fiscal aduz que: "Se vencida, a Fazenda Pública ressarcirá o valor das despesas feitas pela parte contrária."

Outro ponto que merece ser ponderado diz respeito ao benefício que o não ajuizamento de ação como esta traz um benefício para o próprio Poder Judiciário, já abarrotado de ações que dificultam o exercício da atividade judicante de forma célere e eficiente.

Assim, declarar a prescrição ex offício do crédito tributário é poder-dever do Procurador do Estado, em face não apenas do seu poder de autotutela, mas em face à situação de inconstitucionalidade que poderia gerar com o ajuizamento de demandas que afrontam os princípios constitucionais.

O fato é que, da mesma forma que para o lançamento tributário cabe à autoridade fiscal verificar os pressupostos necessários para o lançamento, isto é, avaliar se sobre a obrigação não operou a decadência tributária;no caso do Procurador do Estado, é seu poder-dever verificar se ainda cabe ajuizar a ação de execução. Isso implica verificar a prescrição,conforme dispõe o art. 174 do Código Tributário Nacional.

Ocorre que, como o ato de extinção pressupõe o cancelamento do crédito tributário, o Procurador do Estado, após fundamentar o não ajuizamento da demanda em função da prescrição da pretensão da ação, deve encaminhar o retorno do expediente ao órgão competente para a extinção do crédito que havia sido devidamente constituído. Desta forma, embora possa declarar a prescrição do crédito tributário, não cabe ao Procurador do Estado, em ato isolado, anular o ato de lançamento, pois somente lhe 
seria permitido atuar dentro da sua competência legal, a saber: a defesa em juízo ou fora dele dos interesses do Estado.

Assim, se por um lado é conveniente que as relações jurídicas, a partir de um determinado momento, se sedimentem, evitando incertezas e conflitos perenes, por outro, a lei deve estabelecer os parâmetros necessários para regular atos e comportamentos.

Sem embargos, a existência de direitos subjetivos oponíveis ao próprio Estado é uma conquista expressiva dos tempos modernos. De fato, o respeito ao princípio da segurança jurídica é fundamental para o que se entende por Estado Democrático de Direito.

Ocorre que o Estado de Democrático de Direito deve ser entendido, não somente, mas a partir de um Estado pautado no reconhecimento das leis e das decisões judiciais.

Enquanto os particulares podem fazer tudo que a lei não proíbe, a Administração pública só pode fazer o que a lei autorize.

\section{CONSIDERAÇÕES FINAIS}

A lei deve ser a maestrina a reger os procedimentos necessários para que se possa declarar a prescrição em âmbito administrativo, a fim de que os atos necessários ao reconhecimento não entrem em conflito com as competências exclusivas de seus agentes. É o respeito à tipicidade, a qual determina que a autoridade administrativa deve exercer sua atividade nos termos definidos em lei.

No entanto, a Administração Pública não pode ficar inerte à espera de lei que venha expressamente o autorizar à pratica do ato.

Ajuizar uma ação de cobrança sem estar revestida do suficiente suporte fático, demanda custos à Administração Pública em claro descompasso como os princípios que regem a administração pública. Não há justificativa para ingressar com uma demanda que de antemão sabe-se indevida.

O crédito tributário prescrito reclama, em nome da segurança jurídica, a declaração da prescrição tributária, posto ser um direito individual e de declaração obrigatória pelo ente público. 
Portanto, nos Estados em que há uma cisão nos atos de inscrição e ajuizamento da ação e a lei seja silente em relação à autoridade competente para a prática do ato, cabe à Procuradoria do Estado proceder o reconhecimento ex offício da prescrição, sendo que, se o direito material ao crédito tributário pereceu antes da inscrição em dívida ativa, cabe à autoridade fiscal, responsável pela realização deste procedimento, reconhecer a perda do direito material ao crédito e encaminhar para que o representante do Estado em juízo confirme ou não a perda do direito na via processual. Por sua vez, caso a prescrição ocorra após a inscrição em dívida ativa, o Procurador do Estado, ao reconhecer a prescrição, deve encaminhar o expediente à Secretaria de Estado da Fazenda para que esta proceda à baixa do crédito no sistema, posto faltar-lhe competência para anular um ato de lançamento tributário, realizado com observância do princípio da legalidade.

\section{REFERÊNCIAS}

ÁVILA, Humberto. Segurança Jurídica: entre a permanência, mudança e realização do direito tributário. 2 ed. São Paulo: Malheiros Editores,2012.

BECKER, Alfredo Augusto. Teoria Geral do Direito Tributário.5 ed. São Paulo: Noeses.2010.

CERQUEIRA, Marcelo Fontes de. Repetição de Indébito Tributário. São Paulo: Max Limonad, 2000.

GAGliano, Pablo Stolze, PAMPlOnA FILHO, Rodolfo. Novo Curso de Direito Civil. 9 ed. Ver.,atual. e ampl. São Paulo: Saraiva, 2007.

BARROSO, Luís Roberto.Temas de Direito Constitucional. 2 ed. São Paulo: Renovar, 2002, p.501.

MEIRELES, Hely Lopes. Direito administrativo brasileiro. 19 ed. atualizada. São Paulo: Malheiros, 1994.

MELlo, Celso Antônio de. Curso de Direito Administrativo. 26 ed. São Paulo: Malheiros, 2009.

MONTEIRO, Washington de Barros. Curso de Direito Civil -parte geral, v.1. São Paulo: Saraiva, 2000.

SANTI, Eurico Marcos Diniz. Lançamento tributário. 3 ed. São Paulo: Saraiva, 2010. 
SILVA PEREIRA, Caio Mário. Instituições de direito civil. Rio de Janeiro: Forense, 1993.

SOLUÇÃOdE CONSULTA INTERNAN. ${ }^{\circ} 25$ - Cosit, em 5 de setembro de 2013 minutada por Julio Cesar de Sousa Marinho, Auditor-Fiscal da RFB da Disit da $8^{a}$ Região Fiscal, com revisão de Eduardo Newman de Mattera Gomes, chef da Disit da $8^{a}$ Região Fiscal. Analisado por Eduardo Gabriel Góes Vieira Ferreira Fogaça, chefe da Dinog, com revisão de Mirza Mendes reis, Coordenadora da Copen.

THEODORO JÚNIOR, Humberto. Distinção científica entre prescrição e decadência: um tributo à obra de Agnelo Amorim Filho. Revista dos tribunais, v. 836, jun. 2005.

TONIOLO, Ernesto José. A Prescrição Intercorrente na Execução Fiscal. 2 ed. Rio de Janeiro: Editora Lumen Juris, 2008. 